Research article

\title{
Quantitative determination, by real-time reverse transcription polymerase chain reaction, of aromatase mRNA in invasive ductal carcinoma of the breast
}

\author{
Zhenhuan Zhang ${ }^{1}$, Hiroko Yamashita1, Tatsuya Toyama ${ }^{1}$, Yoko Omoto ${ }^{1}$, Hiroshi Sugiura1, \\ Yasuo Hara ${ }^{1}$, Xueqing Wu${ }^{1}$, Shunzo Kobayashi ${ }^{2}$ and Hirotaka Iwase ${ }^{1}$ \\ ${ }^{1}$ Department of Breast and Endocrine Surgery, Nagoya City University, Medical School, Nagoya, Japan \\ ${ }^{2}$ Department of Surgery, Josai Municipal Hospital of Nagoya, Nagoya, Japan \\ Corresponding author: Hirotaka Iwase (e-mail: h.iwase@med.nagoya-cu.ac.jp)
}

Received: 25 May 2003 Revisions requested: 14 Jul 2003 Revisions received: 19 Aug 2003 Accepted: 12 Sep 2003 Published: 9 Oct 2003

Breast Cancer Res 2003, 5:R250-R256 (DOI 10.1186/bcr657)

(C) 2003 Zhang et al., licensee BioMed Central Ltd (Print ISSN 1465-5411; Online ISSN 1465-542X). This is an Open Access article: verbatim copying and redistribution of this article are permitted in all media for any purpose, provided this notice is preserved along with the article's original URL.

\begin{abstract}
Background: Estrogen is a mitogenic factor that is implicated in the genesis and progression of breast cancer via its binding to estrogen receptor (ER)- $\alpha$. Synthesis of estrogen in situ is believed to be catalyzed mainly by aromatase. Previous studies comparing the relative contributions from tumor cells and stromal cells to local estrogen synthesis, as assessed by immunohistochemical analysis, were quite controversial and no consistent relationship was found between the presence of aromatase and any clinicopathologic factor. In addition, previous studies into aromatase gene expression and clinicopathologic factors are limited.

Methods: We assessed the level of expression of aromatase mRNA, using quantitative real-time RT-PCR, in 162 cases of invasive ductal carcinoma of the breast. Associations between aromatase expression and different clinicopathologic factors were sought.
\end{abstract}

Results: It was found that aromatase mRNA was expressed at significantly higher levels in patients older than 50 years, in those without axillary lymph node involvement, in those with tumor size less than $2 \mathrm{~cm}$, and in ER- $\alpha$ positive tumors. However, no relationship was found between aromatase mRNA expression and any other clinicopathologic factor, including histologic grade and progesterone receptor status. Patients with high levels of expression of aromatase mRNA tended to have a better prognosis than did those patients with low expression.

Conclusion: These findings imply that ER- $\alpha$ and aromatase may be coexpressed in endocrine responsive patients. They may also indicate that aromatase expression could be a marker of endocrine responsiveness, and it may have prognostic implications for breast cancer progression.

Keywords: aromatase mRNA, breast cancer, estrogen receptor, real-time RT-PCR, progesterone receptor, prognosis

\section{Introduction}

It is well established that estrogens are important for the growth and development of normal mammary gland, as well as for the initiation and progression of estrogendependent breast cancer. The effect of estrogens on breast tumorigenesis is believed to be mediated mainly through estrogen receptor (ER)- $\alpha$. Breast cancer occurs more frequently in postmenopausal women than in younger women, and a higher proportion of these older patients have tumors that are sensitive to hormones. In postmenopausal women the concentration of estradiol in breast cancer tissue is reported to be higher than in plasma and normal breast tissue [1]. The high concentration of estradiol in breast cancer tissues of postmenopausal women may be due to in situ synthesis of estrogen by breast tissues, which is believed to be catalyzed mainly by aromatase [2]. Reports of the contribution to in situ estrogen production by stromal cells as opposed to that by breast cancer cells, assessed immunohistochemically, are controversial [3-12]. Some previous 
studies showed no consistent relationship between ER- $\alpha$ status and tumor aromatase levels by immunohistochemistry $[3,4,8,12]$.

The human aromatase gene, CYP19 [13], yields an mRNA that spans nine exons with the translation start site beginning at exon II $[14,15]$. Its transcription is regulated in a tissue-specific manner [16-19]. However, studies of associations between aromatase gene expression and clinicopathologic factors in breast cancer have been limited and the results discordant. In the present study, using quantitative real-time LightCycler RT-PCR (Roche Molecular Biochemicals, Mannheim, Germany), we correlated aromatase mRNA expression with other clinicopathologic factors in 162 cases of invasive ductal carcinoma of the breast.

\section{Materials and methods Patients and sample}

A total of 162 primary invasive ductal breast carcinoma specimens were obtained by surgical excision at the Department of Breast and Endocrine Surgery, Nagoya City University Medical School, Nagoya, Japan between 1992 and 2000. The research protocol for the study was approved by the ethics committee of Nagoya City University Graduate School of Medicine, Nagoya, and informed consent was obtained from all patients before surgery.

Stage I patients without nodal metastasis did not receive any adjuvant therapy. Most of the stage II and III patients, who were ER-positive and/or progesterone receptor $(\mathrm{PgR})$-positive, received adjuvant endocrine therapy using tamoxifen $(20 \mathrm{mg} /$ day, orally) for 5 years. The median age of the patients was 53 years (range 34-88 years), and all patients were women.

Patients were followed postoperatively every 3 months by clinical and radiologic examination. The median follow-up period was 58 months (range 22-90 months). Patients were graded histopathologically according to the modified Bloom and Richardson method proposed by Elston and Ellis [20]. Samples were snap frozen in liquid nitrogen and stored at $-80^{\circ} \mathrm{C}$ until RNA extraction.

\section{Total RNA isolation and reverse transcription}

Total RNA from microscopically confirmed homogeneous breast cancer tissue was isolated from approximately $500 \mathrm{mg}$ of frozen specimen or from one flask of the HepG2 cell line, kindly provided by Dr N Harada [21], as a positive control and to generate standard curves. mRNA was isolated using the Trizol reagent (Life Technologies Inc., Tokyo, Japan) according to the manufacturer's instructions. RT reactions were performed as previously described [22]. Briefly, each $20 \mu \mathrm{l}$ cDNA synthesis mixture contained $1 \mu \mathrm{g}$ total RNA, buffer $(10 \mathrm{mmol} / \mathrm{l}$ Tris- $\mathrm{HCl}[\mathrm{pH}$ 9.0], $\left.50 \mathrm{mmol} / / \mathrm{KCl}, 1.5 \mathrm{mmol} / / \mathrm{MgCl}_{2}\right), 1 \mathrm{mmol} / \mathrm{l}$ each of deoxynucleotide triphosphates, 25 units of RNA-guard RNase inhibitor (Amersham Pharmacia Biotech Inc., Tokyo, Japan), 200 units of Superscript II reverse transcriptase (Life Technologies Inc.), and $100 \mathrm{ng} \operatorname{pd}(\mathrm{N}) 6$ random hexamer (Amersham Pharmacia Biotech Inc.).

\section{Primers and probes}

We conducted Blast searches (GenBank) to confirm the specificity of the nucleotide sequences chosen for the primers and probes, and to confirm the absence of DNA polymorphism. To avoid detection of contaminating genomic DNA, the primers were located at exons 3 and 4 . The specific oligonucleotide primers were synthesized according to published information on the aromatase gene [23] as follows: sense primer 5'-TCT GGA TCT CTG GAG AGG AAA-3' (384-404); and antisense primer 5'-GCC TTT CTC ATG CAT ACC GA-3' (517-498). The PCR product size is 140 base pairs. The donor probe 5'-CTG CCG AAT CGA GAG CTG TAA TGA TT-3' has a fluorescein label at its $3^{\prime}$ end. The acceptor probe $5^{\prime}$-TGC TTC ATT ATG TGG AAC ATA CTT GAG GAC-3' has LC Red 640 at its $5^{\prime}$ end.

To ensure the fidelity of mRNA extraction and reverse transcription, all samples were subjected to PCR amplification with oligonucleotide primers and probes specific for the constitutively expressed glyceraldehyde-3-phosphate dehydrogenase gene (GAPDH) and normalized. GAPDH primers were as follows: forward primer $5^{\prime}$-AAA TCA AGT GGG GCG ATG CTG-3'; and reverse primer 5'-GCA GAG ATG ATG ACC CTT TTG-3'. The sequences of the GAPDH probes used for real-time LightCycler PCR were 5'-AGA AGG CTG GGG CTC ATT TGC AGG G-3' and 5'-GTC CAC TGG CGT CTT CAC CAC CAT G-3'. All primers and probes were purchased from the Japanese Gene Institute (Saitama, Japan).

Real-time reverse transcription polymerase chain reaction PCR was performed using a LightCycler. The PCR reaction was carried out in a $20 \mu$ final volume containing the following: $\mathrm{H}_{2} \mathrm{O}$ up to $20 \mu \mathrm{l} ; 2.4 \mu \mathrm{l} 25 \mathrm{mmol} / \mathrm{MgCl}_{2} ; 0.5 \mu \mathrm{l}$ $20 \mathrm{pmol} / \mu \mathrm{l}$ sense primer and antisense primer; $0.4 \mu \mathrm{l}$ $10 \mathrm{pmol} / \mu \mathrm{l}$ donor and acceptor probe; $2 \mu \mathrm{l} \mathrm{PCR}$ master mix; and $1.5 \mu \mathrm{l}$ cDNA. After an initial denaturation step at $95^{\circ} \mathrm{C}$ for $60 \mathrm{~s}$, temperature cycling was initiated. Each cycle consisted of denaturation at $95^{\circ} \mathrm{C}$ for $0 \mathrm{~s}$, hybridization at $56^{\circ} \mathrm{C}$ for $5 \mathrm{~s}$, and elongation at $72^{\circ} \mathrm{C}$ for $6 \mathrm{~s}$. The fluorescence signal was acquired at the end of the hybridization step. A total of 55 cycles were performed. Cycling conditions for GAPDH were as follows: initial denaturation at $95^{\circ} \mathrm{C}$ for $60 \mathrm{~s}$, followed by 50 cycles at $95^{\circ} \mathrm{C}$ for $0 \mathrm{~s}, 60^{\circ} \mathrm{C}$ for $5 \mathrm{~s}$, and $72^{\circ} \mathrm{C}$ for $8 \mathrm{~s}$.

\section{Standard curves and expression of results}

For each PCR run, a standard curve was constructed from serial dilutions of cDNA from the HepG2 cell line. The level 
of expression of aromatase mRNA is given as relative copy numbers normalized against GAPDH mRNA and shown as mean \pm standard deviation. Relative aromatase mRNA expression was calculated using the formula $(A / G) \times 1000$, where $A$ is the relative copy numbers of aromatase mRNA and $G$ is the relative copy numbers of GADPH mRNA.

A nontemplate control was included in each experiment. All of the nontemplate controls, the standard cDNA dilutions from the HepG2 cell line, and the tumor samples were assayed in duplicate. All of the patient samples with a coefficient of variation for gene mRNA copy number data greater than $10 \%$ were retested using the method of Bieche and coworkers [24].

\section{Immunohistochemical staining of estrogen receptor- $\alpha$ and progesterone receptor}

Immunostaining of ER- $\alpha$ and $\mathrm{PgR}$ was performed as previously described [25]. Briefly, the slides were incubated with anti-ER- $\alpha$ primary antibody (ER1D5; Dako, Kyoto, Japan) at a 1:100 dilution or anti-PgR primary antibody (PgR636; Dako), also at a 1:100 dilution, using the streptavidin-biotin system (SAB-PO kit; Nichirei, Tokyo, Japan) according to the manufacturer's instructions. The immunostaining of ER- $\alpha$ and $\mathrm{PgR}$ was subjectively assessed by two independent investigators ( $\mathrm{ZZ}$ and $\mathrm{HI}$ ), and discordant results were resolved by consultation with a third investigator (HY), as previously described [26]. Expression of ER- $\alpha$ and PgR was scored by assigning a proportion score and an intensity score according to Allred's procedure [27]. In brief, the proportion of positive staining throughout the entire slide was assessed as 0 (negative), 1 (<1\%), 2 (1-10\%), 3 (10-33\%), 4 $(33-66 \%)$ and $5(>66 \%)$, and the average staining intensity was recorded as 0 (negative), 1 (weak), 2 (moderate), or 3 (strong) under light microscopy. The immunohistochemistry score for each slide (0 or 2-8) was obtained as the sum of the proportion and intensity. ER- $\alpha$ and PgR status by immunohistochemistry was then assessed as negative (score $0-2$ ) or positive (score 3-8).

\section{Statistical analysis}

The nonparametric Mann-Whitney U-test was used for statistical analysis of associations between aromatase expression and clinicopathologic factors. Disease free survival curves were generated using the Kaplan-Meier method and verified using log-rank (Mantel-Cox) and Breslow-Gehan-Wilcoxon tests. $P<0.05$ was considered statistically significant.

\section{Results}

\section{Characteristics of the patients}

Clinical characteristics are summarized in Table 1. Of the 162 patients with invasive ductal carcinoma that we examined, 104 patients were older and 58 were younger than
Table 1

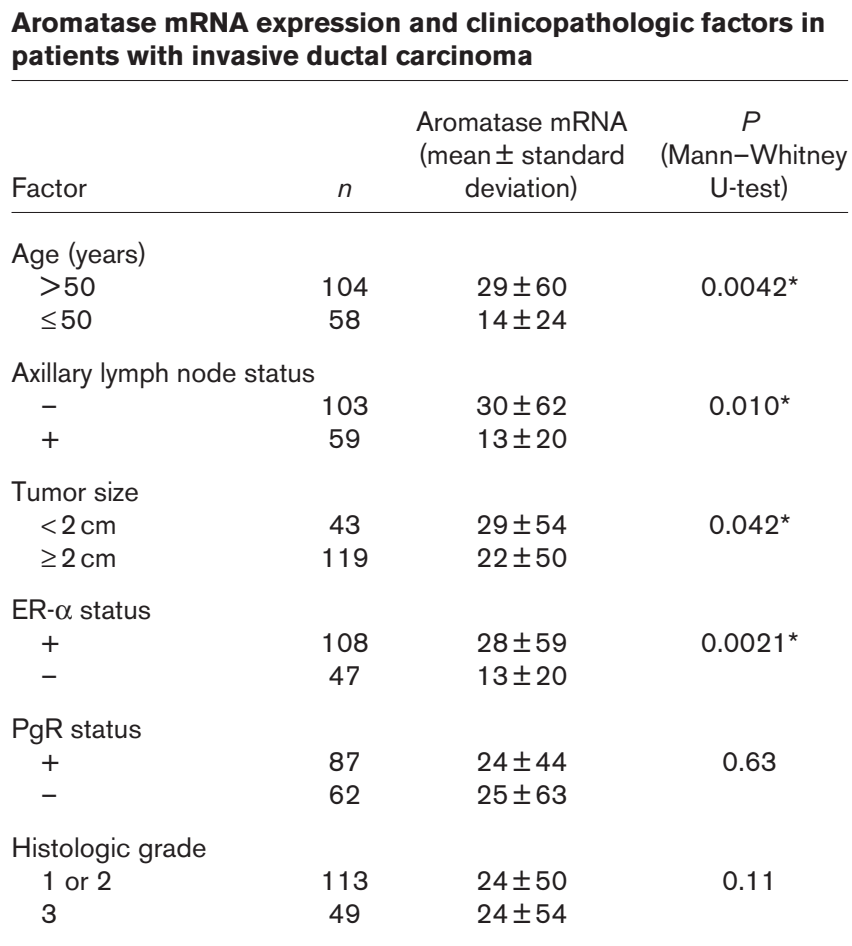

Estrogen receptor $(\mathrm{ER})-\alpha$ status and progesterone receptor $(\mathrm{PgR})$ status were determined histochemically. ${ }^{\star} P<0.05$.

metastases, whereas 103 had no metastases; and in 43 cases the tumor was less than $2 \mathrm{~cm}$ and in 119 cases it was more than $2 \mathrm{~cm}$ in size. By ER- $\alpha$ immunohistochemistry, in 108 cases the tumor was ER- $\alpha$ positive, in 47 cases the tumor was ER- $\alpha$ negative, and in seven cases the ER- $\alpha$ status could not be determined. In comparison, immunohistochemical analysis revealed that in 87 cases the tumor was PgR positive, in 62 cases the tumor was PgR negative, and in 13 cases the PgR status could not be determined. The tumor was classified as not being high grade in 113 patients, whereas in 49 cases histologically high-grade tumor was present. The amount of aromatase mRNA in the 162 cases ranged from 0 to 486 , with a median of 24 relative copy numbers.

\section{Level of expression of aromatase mRNA correlates with age, axillary lymph node metastasis, and tumor size}

The level of aromatase mRNA expression in the group of patients older than 50 years of age $(29 \pm 60)$ was significantly greater than that in the patients younger than 50 years $(14 \pm 24, P=0.0042$; Fig. $1 \mathrm{a})$. The expression in patients lacking axillary lymph node metastases $(30 \pm 62)$ was significantly higher than that in the group with axillary lymph node metastases (13 $\pm 20, P=0.010$; Fig. $1 \mathrm{~b})$. In addition, it was found that the level of aromatase mRNA expression in the group with tumors less than $2 \mathrm{~cm}$ $(29 \pm 54)$ was greater than that in the group with tumors larger than $2 \mathrm{~cm}(22 \pm 50, P=0.042$; Fig. $1 \mathrm{c})$. 

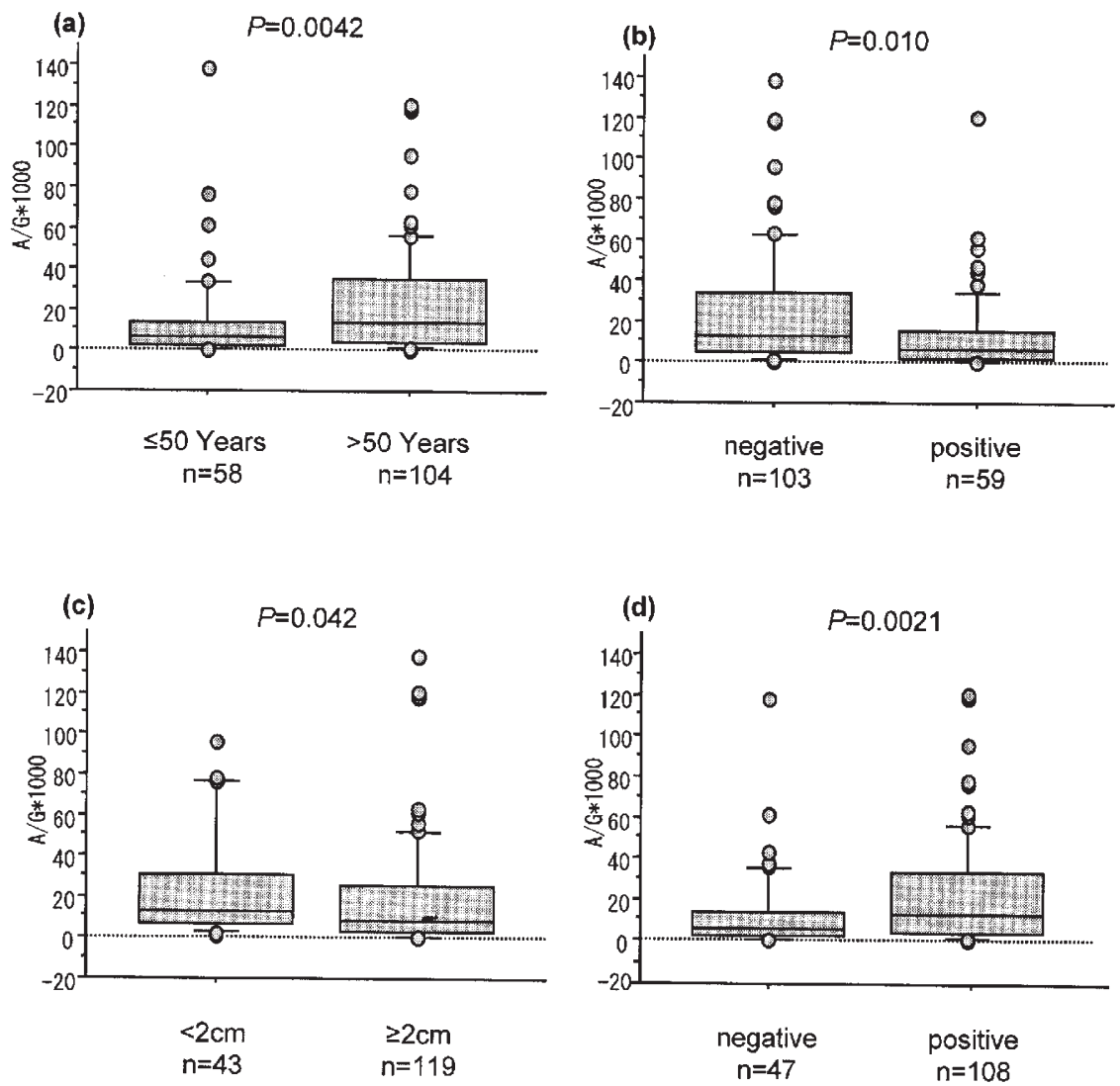

Comparison of aromatase mRNA expression between the following groups: (a) patients older than and those younger than 50 years of age; (b) patients who were negative and those who were positive for lymph node metastasis; (c) patients with tumor size $<2 \mathrm{~cm}$ and those with tumor size $\geq 2 \mathrm{~cm}$; and (d) patients who were estrogen receptor (ER)- $\alpha$ positive and those who were ER- $\alpha$ negative, by histochemistry. The boxes represent the mean and the $70 \%$ confidence intervals; bars are standard deviations. The aromatase mRNA expression was significantly greater in those older than 50 years $(29 \pm 60)$ than in those younger than 50 years $(14 \pm 24 ; P=0.0042)$. It was significantly greater in samples negative for lymph node metastasis $(30 \pm 62)$ than in samples positive for lymph node metastasis $(13 \pm 20 ; P=0.010)$. The aromatase mRNA expression was significantly greater in the group with tumor size $<2 \mathrm{~cm}(29 \pm 54)$ than in the group with tumor size $\geq 2 \mathrm{~cm}(22 \pm 50 ; P=0.042)$. Finally, it was significantly greater in the ER- $\alpha$ positive group (28 \pm 59$)$ than in the ER- $\alpha$ negative group $(13 \pm 20 ; P=0.0021)$.

Level of expression of aromatase mRNA correlates with immunohistochemically determined esterogen receptor- $\alpha$ protein expression

The level of aromatase mRNA expression was also found to be higher in the immunohistochemically determined ER- $\alpha$ positive group $(28 \pm 59)$ than that in the negative group (13 $\pm 20, P=0.0021$; Fig. 1d). However, there was no difference in the level of aromatase mRNA expression between the PgR positive and negative groups by immunohistochemical PgR detection. We also analyzed aromatase mRNA expression in the subgroups of women who were premenopausal and postmenopausal, but we did not find any significant correlation (data not shown), which was probably due to the small number of individuals in the subgroups.
The level of expression of aromatase mRNA and other clinicopathologic factors and prognosis

The level of aromatase mRNA expression was not found to be significantly correlated with any other clinicopathologic factor, including histologic grade (Table 1). To identify a cutoff point for aromatase mRNA expression that is clinically meaningful with respect to prognosis, various levels of aromatase mRNA expression were tested using the Kaplan-Meier method and verified using log-rank (MantelCox) and Breslow-Gehan-Wilcoxon tests. When the cutoff point of aromatase mRNA level was set at 10, patients with high level aromatase mRNA expression $(46 \pm 68, n=77)$ tended to have a better prognosis than did those with low expression ( $4 \pm 3, n=85$; log-rank test $P=0.073$; BreslowGehan-Wilcoxon test $P=0.035$; Fig. 2). 
Figure 2

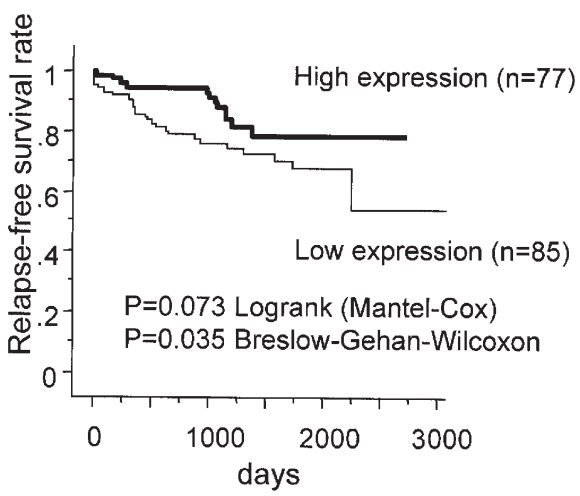

Statistical analysis of aromatase mRNA expression levels and disease free survival, using the Kaplan-Meier method. The patients with high aromatase mRNA expression in their tumors $(46 \pm 68)$ exhibited a trend toward better prognosis than did those with lower expression $(4 \pm 3$; log-rank [Mantel-Cox] test $P=0.073$; Breslow-Gehan-Wilcoxon test $P=0.035$ )

\section{Discussion}

The mitogenic activity of estrogens in the promotion and progression of estrogen responsive breast cancer is well established, and is mediated mainly via ER- $\alpha$. In situ estrogen synthesis catalyzed by aromatase plays an important role in breast cancer, especially in postmenopausal patients, whose ovarian function has ceased. The final, rate limiting step in estrogen biosynthesis is controlled by the cytochrome P450-type enzyme complex aromatase. Previous studies of the immunohistochemical localization of aromatase in breast cancer have been controversial. Some studies utilizing either monoclonal $[6,8]$ or polyclonal antibodies [5,12] localized aromatase mainly to the tumor cells. However, other studies that utilized polyclonal antibodies $[7,10,11]$ reported that aromatase was mainly detectable in the stromal cells. Our previously published results are consistent with those studies that reported positive cytoplasmic staining in both stromal and tumor cells [26].

Previous studies concerning the detection of aromatase expression by immunohistochemistry and its association with clinicopathologic factors, especially with ER- $\alpha$, failed to produce consistent results. Esteban and coworkers [3] first detected aromatase immunoreactivity using a specific polyclonal antibody against human placental aromatase in the cytoplasm of carcinoma cells; they showed a significant, but inverse, correlation between aromatase activity and the ER- $\alpha$ status $(P=0.04)$. This indicated increased likelihood of negative estrogen status if substantial aromatase activity was present [3]. In a study conducted by Sasano and coworkers [4], aromatase immunoreactivity in the stromal cells and/or adipocytes of breast cancer tissue
PgR positive carcinoma cells, including cases in which ER- $\alpha, P g R$, and aromatase were detected in the same specimens. Brodie and coworkers [12] reported that tumors with relatively high aromatase activity tend to be ER- $\alpha$ positive; six out of nine ER positive tumors expressed aromatase, whereas six out of 10 ER negative tumors lacked aromatase. Miller and coworkers [28] also observed a significant trend toward an association between aromatase activity and the presence of ER- $\alpha$, although tumors expressing active aromatase included both ER- $\alpha$ positive and negative tumors. It is difficult to postulate a role for estrogens produced in situ in tumors that lack ERs [8]. Our previous studies showed that the level of aromatase expression was not correlated with ER- $\alpha$ and PgR, as detected by immunohistochemistry, or with any other clinicopathologic factors including age, tumor size, axillary lymph node involvement and histologic grade, either in tumor cells or in stromal cells [26].

Because of the above discrepancies, we felt that investigating aromatase gene expression could shed light on the functional significance of aromatase in breast cancer. Earlier studies of aromatase mRNA expression in breast cancer are limited. It was reported that levels of aromatase mRNA were highest in a tumor bearing quadrant [29], and were significantly higher than in those regions distal to the tumor or in nonmalignant breast tissue [30]. The presence of aromatase mRNA was found to correlate with enzyme activity [31]. However, one study [32] indicated that, although there is a positive correlation between aromatase transcript levels and enzyme activity, this failed to achieve statistical significance. Therefore, whereas aromatase mRNA quantification may be an option for monitoring the potential of tumor tissue to synthesize estrogens, it may not accurately reflect enzyme activity in a minority of tumors. In the present study it was found that aromatase mRNA expression was significantly greater in ER- $\alpha$ positive than in ER- $\alpha$ negative patients. This finding is not consistent with earlier studies that failed to show a relationship between aromatase mRNA levels and ER- $\alpha$ $[33,34]$. The discrepancy may be due to differences in the methodology applied to detect ER- $\alpha$. In one earlier study [33] ER- $\alpha$ protein levels in breast cancer were assessed by enzyme immunoassays, and in another study [34] ER- $\alpha$ protein levels in breast cancer were assessed using dextran coated charcoal method until 1988 and enzyme immunoassay thereafter. In the present study, however, immunohistochemical methodology was employed. Another reason for the discrepancy between studies regarding the relationship of ER- $\alpha$ with aromatase mRNA level may be that aromatase is distributed mainly in tumor cells or stromal cells, but this is controversial.

The higher level of aromatase mRNA expression in patients older than 50 years and with tumor size less than $2 \mathrm{~cm}$, but who are ER- $\alpha$ positive and axillary lymph node 
negative (taken together with a previous study [33] that documented higher aromatase mRNA expression in the group negative for lymph node metastasis group) may imply that ER- $\alpha$ and aromatase may be coexpressed in endocrine responsive patients. This may further suggest that aromatase gene expression could be a potential endocrine responsiveness marker and may have prognostic significance in breast cancer.

\section{Conclusion}

Despite the limited number of patients involved in this study (only 162 cases), the significant correlation between aromatase mRNA expression and age over 50 years, negative lymph node metastasis, smaller tumor size, ER- $\alpha$ positive status, and better prognosis imply that ER- $\alpha$ and aromatase may be coexpressed in endocrine responsive patients. Our findings also indicate that aromatase gene expression is a potential marker of endocrine responsiveness and may have prognostic significance in breast cancer. Further studies, including a larger number of cases, microdissected breast tumor tissue, and longer periods of follow up, are warranted to elucidate the functional significance of aromatase in breast cancer.

\section{Competing interests}

None declared.

\section{Acknowledgements}

This work was supported in part by a grant-in-aid (project number 14370362) for scientific research from the Ministry of Education, Science and Culture of Japan. ZZ was supported by a Medical PhD Fellowship from Japanese Government (number A1022AD012). The authors wish to thank Ms Mariko Nishio for her excellent technical support.

\section{References}

1. van Landeghem AA, Poortman J, Nabuurs M, Thijssen JH: Endogenous concentration and subcellular distribution of estrogens in normal and malignant human breast tissue. Cancer Res 1985, 45:2900-2906.

2. Yue W, Wang JP, Hamilton CJ, Demers LM, Santen RJ: In situ aromatization enhances breast tumor estradiol levels and cellular proliferation. Cancer Res 1998, 58:927-932.

3. Esteban JM, Warsi Z, Haniu M, Hall P, Shively JE, Chen S: Detection of intratumoral aromatase in breast carcinomas. An immunohistochemical study with clinicopathologic correlation. Am J Pathol 1992, 140:337-343.

4. Sasano $H$, Nagura $H$, Harada N, Goukon $Y$, Kimura M: Immunolocalization of aromatase and other steroidogenic enzymes in human breast disorders. Hum Pathol 1994, 25: 530-535.

5. Berstein LM, Larionov AA, Kyshtoobaeva A, Pozharisski KM, Semiglazov VF, Ivanova OA: Aromatase in breast cancer tissuelocalization and relationship with reproductive status of patients. J Cancer Res Clin Oncol 1996, 122:495-498.

6. Shenton KC, Dowsett M, Lu Q, Brodie A, Sasano H, Sacks NP, Rowlands MG: Comparison of biochemical aromatase activity with aromatase immunohistochemistry in human breast carcinomas. Breast Cancer Res Treat 1998, Suppl 1:S101-S107; discussion S109-S119.

7. Santen RJ, Martel J, Hoagland M, Naftolin F, Roa L, Harada N, Hafer L, Zaino R, Pauley R, Santner S: Demonstration of aromatase activity and its regulation in breast tumor and benign breast fibroblasts. Breast Cancer Res Treat 1998, Suppl 1:S93S99; discussion S109-S119.
8. Lu Q, Nakmura J, Savinov A, Yue W, Weisz J, Dabbs DJ, Wolz G, Brodie A: Expression of aromatase protein and messenger ribonucleic acid in tumor epithelial cells and evidence of functional significance of locally produced estrogen in human breast cancers. Endocrinology 1996, 137:3061-3068.

9. Sasano H, Frost AR, Saitoh R, Harada N, Poutanen M, Vihko R, Bulun SE, Silverberg SG, Nagura H: Aromatase and 17 betahydroxysteroid dehydrogenase type 1 in human breast carcinoma. J Clin Endocrinol Metab 1996, 81:4042-4046.

10. Santner SJ, Pauley RJ, Tait L, Kaseta J, Santen RJ: Aromatase activity and expression in breast cancer and benign breast tissue stromal cells. J Clin Endocrinol Metab 1997, 82:200208.

11. Sasano $\mathrm{H}$, Murakami $\mathrm{H}$ : Immunolocalization of aromatase in human breast disorders using different antibodies. Breast Cancer Res Treat 1998, Suppl 1:S79-S84; discussion S109S119.

12. Brodie A, Lu Q, Nakamura J: Aromatase in the normal breast and breast cancer. J Steroid Biochem Mol Biol 1997, 61:281286.

13. Nelson DR, Kamataki T, Waxman DJ, Guengerich FP, Estabrook RW, Feyereisen R, Gonzalez FJ, Coon MJ, Gunsalus IC, Gotoh O: The P450 superfamily: update on new sequences, gene mapping, accession numbers, early trivial names of enzymes, and nomenclature. DNA Cell Biol 1993, 12:1-51.

14. Means GD, Mahendroo MS, Corbin CJ, Mathis JM, Powell FE, Mendelson CR, Simpson ER: Structural analysis of the gene encoding human aromatase cytochrome P-450, the enzyme responsible for estrogen biosynthesis. J Biol Chem 1989, 264: 19385-19391.

15. Harada N, Yamada K, Saito K, Kibe N, Dohmae S, Takagi Y: Structural characterization of the human estrogen synthetase (aromatase) gene. Biochem Biophys Res Commun 1990, 166: 365-372.

16. Means GD, Kilgore MW, Mahendroo MS, Mendelson CR, Simpson ER: Tissue-specific promoters regulate aromatase cytochrome P450 gene expression in human ovary and fetal tissues. Mol Endocrinol 1991, 5:2005-2013.

17. Mahendroo MS, Means GD, Mendelson CR, Simpson ER: Tissue-specific expression of human P-450AROM. The promoter responsible for expression in adipose tissue is different from that utilized in placenta. J Biol Chem 1991, 266: 11276-11281.

18. Harada N, Utsumi T, Takagi Y: Tissue-specific expression of the human aromatase cytochrome P-450 gene by alternative use of multiple exons 1 and promoters, and switching of tissuespecific exons 1 in carcinogenesis. Proc Natl Acad Sci USA 1993, 90:11312-11316.

19. Harada N, Utsumi T, Takagi Y: Molecular and epidemiological analyses of abnormal expression of aromatase in breast cancer. Pharmacogenetics 1995, 5:S59-S64.

20. Elston CW, Ellis IO: Pathological prognostic factors in breast cancer. I. The value of histological grade in breast cancer: experience from a large study with long-term follow-up. Histopathology 1991, 19:403-410.

21. Harada N, Hatano O: Inhibitors of aromatase prevent degradation of the enzyme in cultured human tumour cells. $\mathrm{Br} J$ Cancer 1998, 77:567-572.

22. Toyama $T$, Iwase $H$, Watson $P$, Muzik H, Saettler E, Magliocco A, DiFrancesco L, Forsyth P, Garkavtsev I, Kobayashi S: Suppression of ING1 expression in sporadic breast cancer. Oncogene 1999, 18:5187-5193.

23. Harada N: Cloning of a complete cDNA encoding human aromatase: immunochemical identification and sequence analysis. Biochem Biophys Res Commun 1988, 156:725-732.

24. Bieche I, Laurendeau I, Tozlu S, Olivi M, Vidaud D, Lidereau R, Vidaud M: Quantitation of MYC gene expression in sporadic breast tumors with a real-time reverse transcription-PCR assay. Cancer Res 1999, 59:2759-2765.

25. Kobayashi S, Ito Y, Ando Y, Omoto Y, Toyama T, Iwase H: Comparison of five different antibodies in the immunohistochemical assay of estrogen receptor alpha in human breast cancer. Breast Cancer 2000, 7:136-141.

26. Zhang $Z$, Yamashita $H$, Toyama $T$, Hara $Y$, Omoto $Y$, Sugiura $H$, Kobayashi S, Harada N, Iwase H: Semi-quantitative immunohistochemical analysis of aromatase expression in ductal carcinoma in situ of the breast. Breast Cancer Res Treat 2002, 74:47-53. 
27. Harvey JM, Clark GM, Osborne CK, Allred DC: Estrogen receptor status by immunohistochemistry is superior to the ligandbinding assay for predicting response to adjuvant endocrine therapy in breast cancer. $J$ Clin Oncol 1999, 17:1474-1481.

28. Miller WR, Anderson TJ, Jack WJ: Relationship between tumour aromatase activity, tumour characteristics and response to therapy. J Steroid Biochem Mol Biol 1990, 37:1055-1059.

29. Bulun SE, Price TM, Aitken J, Mahendroo MS, Simpson ER: A link between breast cancer and local estrogen biosynthesis suggested by quantification of breast adipose tissue aromatase cytochrome P450 transcripts using competitive polymerase chain reaction after reverse transcription. J Clin Endocrinol Metab 1993, 77:1622-1628.

30. Utsumi T, Harada N, Maruta M, Takagi Y: Presence of alternatively spliced transcripts of aromatase gene in human breast cancer. J Clin Endocrinol Metab 1996, 81:2344-2349.

31. Evans CT, Corbin CJ, Saunders CT, Merrill JC, Simpson ER, Mendelson CR: Regulation of estrogen biosynthesis in human adipose stromal cells. Effects of dibutyryl cyclic AMP, epidermal growth factor, and phorbol esters on the synthesis of aromatase cytochrome P-450. J Biol Chem 1987, 262:6914-6920.

32. Sourdaine P, Mullen P, White R, Telford J, Parker MG, Miller WR: Aromatase activity and CYP19 gene expression in breast cancers. J Steroid Biochem Mol Biol 1996, 59:191-198.

33. Miyoshi Y, Ando A, Shiba E, Taguchi T, Tamaki Y, Noguchi S: Involvement of up-regulation of 17beta-hydroxysteroid dehydrogenase type 1 in maintenance of intratumoral high estradiol levels in postmenopausal breast cancers. Int J Cancer 2001, 94:685-689.

34. Girault I, Lerebours F, Tozlu S, Spyratos F, Tubiana-Hulin M, Lidereau R, Bieche I: Real-time reverse transcription PCR assay of CYP19 expression: application to a well-defined series of post-menopausal breast carcinomas. J Steroid Biochem Mol Biol 2002, 82:323-332.

\section{Correspondence}

Hirotaka Iwase, MD, PhD, Department of Breast and Endocrine Surgery, Nagoya City University Medical School, Kawasumi 1, Mizuhoku, Nagoya 467-8601, Japan. Tel +8152 853 8231; fax: +81 52853 6440; e-mail: h.iwase@med.nagoya-cu.ac.jp 